\title{
The Lexicon Of The African American English In Georgia Doyle Johnson's Frederick Douglas And Loraine Hansberry's $A$ Raisin In The Sun
}

\author{
Nizamuddin Sadiq \\ Islamic University of Indonesia
}

\begin{abstract}
To comprehend that a language belongs to a dialect, one may examine its lexicon. As it is considered non-standard dialect, the American African English lexicon is assumed to have its own characteristic different from the standard American English. Therefore, to gain a better comprehension of the American African English dialect in the view point of lexicon features, the paper will elaborate Georgia Doyle Johnson's Frederick Douglas And Loraine Hansberry's A Raisin In The Sun.

This paper is descriptive linguistics rather than a stylistic study as it does not focus on literary style. The data taken was classified into linguistic elements and was tested to the theories of informal English in general; African American English in particular and Standard American English rules of pronunciation. The research findings were summarized and discussed to conclude the research.

The result of the research demonstrates that African American English, a variant of informal English, is different from the rules of Standard American English. In terms of lexicon, African American English employs local and rude words. The presence of slang and colloquialisms, taboo words and swearing make it distinctively informal.
\end{abstract}

Key words: lexicon, dialect, the African American English

\section{A. Introduction}

Sidnell (2006) describes that in general, African American English (African American Vernacular English) vocabularies are the same as other varieties of English. However, African American English speakers employ some 
words which are not found in other varieties and furthermore use some English . words in ways that differ from the standard dialects. A number of words used in Standard English may also have their origin in African American English or at least in the West African languages that contributed to the development of African American English. In addition to words with clearly African origins, however, African American English has a separate vocabulary of words which have no Standard English- language equivalent or with strikingly different meanings from their common usage in Standard American English.

\section{B. Discussion}

Linguistic elements play an important role in language. By comprehending these features, a language structure can be identified. Therefore, in order to have a more complete discussion, this section will describe one linguistic element that is lexicon.

\section{B.1 Lexicon}

African American English employs a high frequency of informal words, as seen below.

\section{B.1.1 The Use In This World and Around Here as Expletives}

An expletive is a word or phrase that does not contribute any meaning to a sentence but is added only to fill out a sentence. African American English frequently uses in this world as an expletive:

I wouldn'tkiss that woman good-by for nothing in this world this way. Not for nothing in this world (ARITS);

Baby, don't nothing happen for you in this world 'less you pay somebody off(ARITS);

That is just what's wrong with the colored woman in this world (ARITS);

Iknow ain ' nothing in this world as busy as you (ARITS);

But it 's all I got in the world (ARITS);

That was the most marvelous things in the world (ARITS).

African American English also employs around here and 'round here as an expletive, for example:

You'll be fussing and cussing 'round here like a madman (ARITS):

I have never asked anyone around here to do anything for me (ARITS); 
I don't want nothing but for you to stop acting holy 'round here (ARITS);

Ijust ain't going to have you 'round here reciting the scriptures in the rain-you hear me? (ARITS);

I am going to be a doctor and everybody around here better understand that! (ARITS);

Oh, ain twe getting ready 'round here, though! (ARITS).

\section{B.1.2 The Use of ABunch of}

Quirk et al (1985:250) state that instead of specific quantities, African American English frequently uses a bunch of Bunch is also applied to people, . meaning a group. Many examples are found in A Raisin in the Sun:

A bunch of stinking niggers! (ARITS);

A bunch of crazy good-for-nothing loudmouths (ARITS);

A bunch of hustling people (ARITS).

\section{B.1.3 The use of Sure as an Intensifier}

Typical intensifiers in informal speech are: real, plain, awful, mighty, pretty, sure. The intensifier that emerges frequently in A Raisin in the Sun is sure. The following are examples.

He sure was a fine man, all right (ARITS);

Yes- and Africa sure is claiming her own tonight (ARITS);

But he sure loved his children (ARITS);

Yes, he sure could (ARITS);

Lord, I sure don't feel like whipping nobody today (ARITS);

They said they're sure going to be glad to see you when you get there (ARITS).

\section{B.1.4 The High Frequency of Using About}

According to Leech and Svartvik (709), the word about can be combined with a considerable range of verbs and adjectives in informal conversations. In African American English about is used as a subordinator for finite clauses. For instance:

And what you know about who is just a good-for-nothing loudmouth?

All anyone seems to know about when it comes to Africa is Tarzan-

InARaisin in the Sun the use of about is very high. The examples.found are:

Talkabout, mad about, pleasant 'bout, know about, think'bout, be about, 


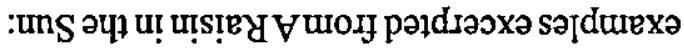

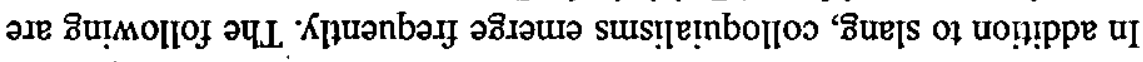

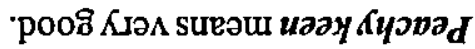

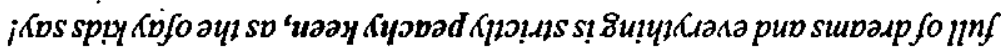

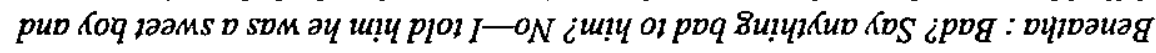

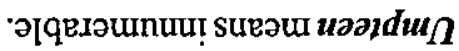

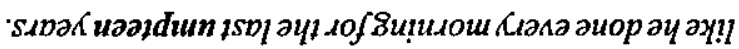

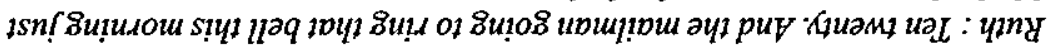

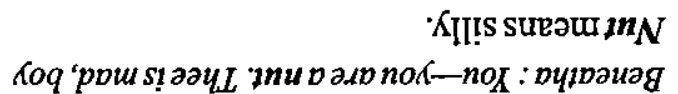

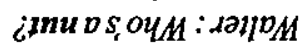

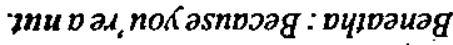

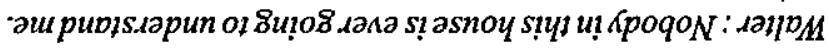

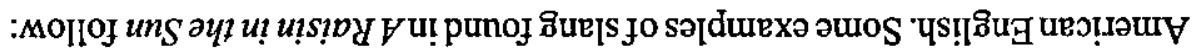

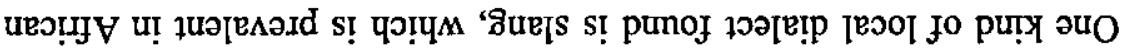

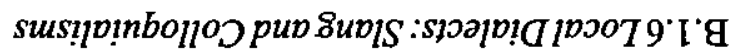
'(SLIJV) !nap aqu so Kdaals $1 s n ! u_{a} I$ 'oN

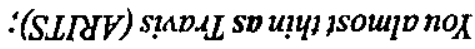
'(SLIAV) II $\therefore(S L I J F)$ Kop sp uTpld isn厂

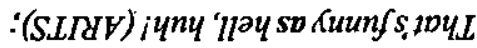

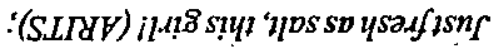

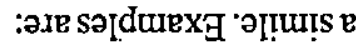

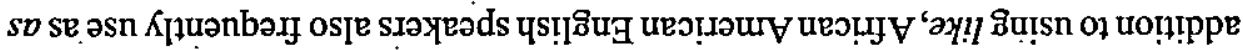

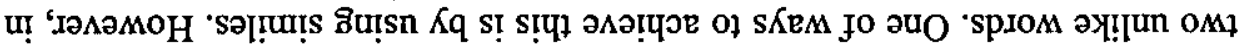

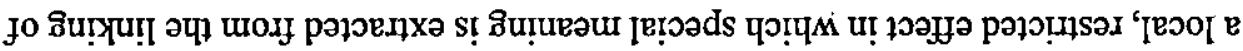

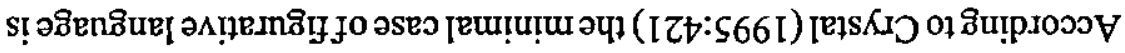

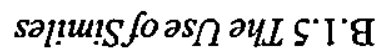

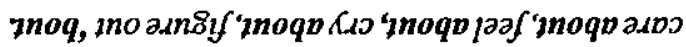

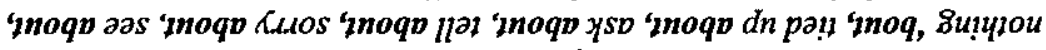

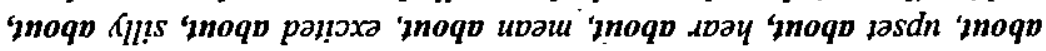

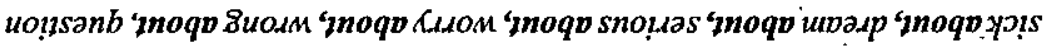

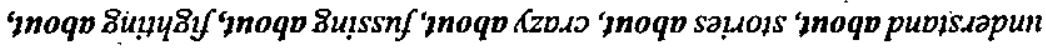


Ruth : Come here. If you don't take this comb and fix this here head, you better!

Fix this here head means arrange the hair.

Ruth : Get carfare and milk money-and not a single penny for no caps, you hear me?

Not a single penny means don't spend any money.

Mama: We ain 't no business people, Ruth. Wejus plain working folks.

Folks means people, usually ordinary.

Mama: (To Beneatha) Whyyou got to flit so from one thing to another, baby?

Flit means move quickly from one place to another.

Beneatha : Brother is aflip-let's face It.

Flip means a flippant person.

Mama : You must not dislike people 'cause they well off, honey.

Well off means rich.

Ruth : You got good children. They just a little off sometimes-but they are good.

Off means not good. For example if milk goes off, that means it is sour, not good to drink.

Beneatha: You mean save them from heathenism-.

Aheathen is a person whose morals are disapproved of.

Beneatha : (Quickly) Oh, no-not ugly (more slowly, apologetically) But it's so hard to manage when it s, well-raw.

Raw means naked, uncovered.

Mama : (Looking at him as she would Walter). I bet you don ' halflook after yourself, being awa y from your mama either. I spec you better come 'round here from time to time to get yourself some decent home-cooked meals....

I bet means I think I'm certain. Decent means likeable, satisfactory, in this case means healthy, wholesome.

Ruth: Now that's truth-it's what ain't been done to it! You expect this boy to . go out with you withyour head all nappy like that?

Nappy means frizzy, uncombed. 
Lindner : Well-you see our community is made up of people who've worked hard as the dickens foryears to build up that little community.

Dickens is used here to mean the devil, Satan.

Ruth: Lord have mercy, ain't this the gall!

Gall means impudence.

Bentha : (Wearily) Oh, I just mean I couldn't ever really be serious about George. He's-he's so shallow.

Ruth : Shallow-what do you mean he's shallow? He's rich.

Shallow means not earnest, sound or serious.

Mama: Seems like you getting to a place where you always tied up in sone kind of knot about something.

Tied up in a knot means nervous.

Mama : ... if we could and how to stay alive and still have a pinch of dignity too...

Pinch means a little bit-like a pinch of salt .

Additionally, a large variety of colloquialisms in greetings and addressing people are found in African American English, such as the ones seen below:

Ruth to Walter: You better get up from there, man!

:Honey,you never say something new.

Ruth to Travis : Get down them steps, boy!

$$
\text { : You go on out and play now, baby. }
$$

Walter to Beneatha : You just got your mother's interest at heart, ain't you, girl?

Beneatha to Walter: Brother, where did Ruth go?

Mama : Now don't you start, child. It 's too early in the morning to be talking about money. It ain ' Christian.

Ruth to Beneatha: Well-what other qualities a man got to have to satisfy you, little girl? follows:

If the speaker is angry, she/he uses a complete name for emphasis, as

Ruth to Walter : Walter Lee Younger, get down off that täble and stop acting like a fool...

Mama : Well-whether they drinks it or not ain't none of my business.

...(Stopping suddenly and studying her daughter-in-law) Ruth Younger, 
what's the matter with

you today? You look like you could fall over right there.

In the time of slavery, which is when A Raisin in the Sun was set, African Americans addressed white people formally when meeting them face-to-face. In private, however, they used colloquialisms among themselves, as in the following examples:

Mama: Where you been?

Walter: Made a call.

Mama: To who, son?

Walter: To The Man.

Mama: What mán, baby?

Walter: The Man, Mama. Don't you who The Man is?

Ruth: Walter Lee?

Walter:The Man. Like the gitys in the streets say-The Man. Captain Boss-Mistuh Charley-Old Cap'n, Please Mr. Bossman...

Walter:We's ain't gwine come out deh dirty up yo' white folks neighbourhood...

Walter: and these here Chicago peckerwoods is some bad peckerwoods

Walter: Cause it sounds respectable to ' $\mathrm{em}$. Something white people get too.

\section{B.1.7Rude Words}

Rude expressions, such as taboo words and swearing are commonly employed in African American English. Several examples of rude expressions are:

(Shrugging) How much cleaning can a. horse need, for Christ's sake (ARITS);

...there simply is no blasted God-ARITS);

Well, for God's sake-if the moving men are here-LET'SGET THE HELL OUTOF HERE! (ARITS);

A bunch of stinking Niggers (ARITS):

Fagotty-(looking) (ARITS).

Swear words are used frequently, as seen in the examples below:

DAMNMYEGGS-DAMNALL THE EGGS THATEVER WAS (ARITS);

Who the hell told you you had to be a doctor? (ARITS);

That 's funny as hell, huh! (ARITS); 
You contented son-of-a-bitch, you happy? (ARITS);

Well, I'll be damned. So, that's what they mean by African Bush (ARITS);

...to say good bye to these goddamned cracking walls! (ARITS);

Then tell me, goddamit... (ARITS).

\section{Conclusion}

The results of the research demonstrate that African American English, a variant of informal English, breaks the rules of Standard American English. In terms of lexicon, African American English employs local and rude words. The presence of slang and colloquialisms, taboo words and swearing make it distinctively informal. Several features. of the African American' English are characterized by: a) using as as a simile, b) around here or "round here, c) in thisworld as an expletive, d) the non specific quantifier a bunch of, e) and the intensifier sure.

Additionally, slang and colloquialisms are: nut, umpteen, fix this here head, not a single penny, folks, flit, well off, off, heathen, decent, nappy, living gall, knot and pinch. A large variety of colloquialisms in greeting and addressing people are informal, for instance: honey, man, boy, baby, girl, brother, child, and little girl. It demonstrate that the speakers of the African American English when they talk within their own communities they innovate new words. In this case, words/phrases/usages that are probably the African American origin are $f x$ thishere head, flit about, youngun, spec, dickens, nappy (for hair or head; the Brits and Aussies use nappy to mean diapers!), conked head, gall (for emotion) and peachy keen. However, it is not always a word or phrase that is unique; it is the way uses them. For example, gall is a legitimate word, but their meaning is different from the one in the dictionary. Another example of word Slap is a legitimate word too, but the African American people might say slap upside the head, which is unique.

The African American English speakers employ polite expressions when they greet people and use please when they ask for permission, while to show respect, African American English speakers use titles such as Miss, Mrs., Mr.,Aunt or Uncle. Furthermore, when the speaker is angry, she/he uses a complete name for emphasis. 
Finally, African American English frequently uses rude expressions such as taboo words and swearing, for example, blasted God, for God's sake, for Christ's sake, nigger, fagotty, damn, son-of-a-bitch, the hell, damned, goddamned, and goddamit.

\section{BIBILIOGRAPHY}

African American Vernacular English. Retrieved From World Wide Web: http://www.biocrawler.com/encyclopedia/.Date of access: Nov 12, 2006

Azhar, B. S. (1993) Fundamentals of English Grammar: Edisi Inggris-Indonesia. 2nd Edition. Jakarta: Bina Rupa Aksara

Baugh, A. C., and Cable, T. (1978) A History of English Language. Englewood Cliffs: Prentice-Hall Inc.

Carter, R. (1999) Standard English: The Widening Debates in Bex, T and Watts, R.J. (eds.), "Standard Grammar, Spoken Grammar: Some Educational Implication." London: Routledge. Pp. 149-165

Chaika, E. (1982) Language the Social Mirror. Massachusetts: Newbury House Publishers, Inc.

Collins, B., and Mees, I. M., (2003) Practical Phonetics and Phonology. A Resource Book for Students. London and New York: Routledge

Cruse, D. A. (1986) Lexical Semantics. Cambridge: Cambridge University Press

Crystal, D. (1995) The Cambridge Encyclopedia of the English Language. Cambridge: Cambridge University Press

Hansberry, L. (1958) A Raisin in the Sun. New York: Vintage Books

Holmes, J. (2001) An Introduction to Sociolinguistics. Harlow: Pearson Educational Limited

Jackson, H. (1982) Analysing English. An Introduction to Descriptive Linguistics. $2^{\text {nd }}$ Edition. Pergamon Press Limited.

Johnson, G. D., Frederick Douglas in Kral (1997) Plays for Reading: Using Drama in EFL. Washington: United StateInformation Agency 
Laundrum-Brown, J. Black English. Retrieved From World Wide Web: http:/geoffbarton.co.uk.files/. Date of Access: March 15, 2006

Leech, G. N., and Svartvik, J. (1975) A Communicative Grammar of English. $2^{\text {nd }}$ Edition. London and New York: Longman

McManis, C (ed) (1987) Language Files. Materials for an Introduction to Language. Ohio: Advocate Publishing Group

Poedjosoedarmo, S. (1976) RagamTutur Ringkas Bahasa Indonesia. Pp. 27-35. (1979) Tingkat Tutur Bahasa Jawa. Jakarta: Pusbinbangsa (1979) Kode Tutur Masyarakat Jawa. Yogyakarta: UGM

Quirk, R. Greenbaum, S., Leech, G., and Svartvik, J. (1985) A Comprehensive Grammar of the English Language. Volumes 1 and 2. London and New York: Longman

Quirk, R. and Greenbaum (1973) A University Grammar of English. England: Longman

Shepperd, V. (1994) Literature About Language. London: Routledge

Sidnel, J. African American Vernacular English (Ebonics). Retrieved From World Wide Web: http://www.une.edu.ourlangnet.aave.htm. Date of access: Nov 12,2006

Stewart, M. M. (ed) (1978) Business English and Communications. New York: McGraw Hill Book Company

Thompson, A. J., and Martinent, V. (1986) A Practical English Grammar $4^{\text {th }}$ Edition. Oxford: Oxford University Press

Trudgill, P. (1999) Standard English: The Widening Debates in Bex, T and Watts, R.J. (eds.), "Standard English: What It Isn't?" London: Routledge. Pp. 117-128

Wardhaugh, R. (1992) An Introduction to Sociolinguistics. Oxford and Cambridge: Blackwell

Wolfram, W. and Christian, D. (1984) Dialect and Education. Issues and Answers. New Jersey: Prentice Hall Regents 